\title{
ANALISIS PERLAKUAN BIAYA PENYELENGGARAAN IBADAH HAJI DALAM PERSPEKTIF AKUNTANSI
}

\author{
Khotibul Umam $^{1 *}$, Zainal Abidin ${ }^{2 *}$, Farid Firmansyah ${ }^{3 \#}$ \\ *Dosen FEBI IAIN Madura: E-mail Umamsibly@gmail.com \\ *Dosen FEBI IAIN Madura: E-mail zainal,madura@gmail.com \\ \#Dosen FEBI IAIN Madura: E-mail farid.firmansyah79@gmail.com
}

\begin{abstract}
Accounting standard is the basic concept urgently needed in the arrangement and development of the guidelines of accounting management on a certain asset, be it debt or equity in the management of hajj cost (BPIH standing for Biaya Penyelenggaran Ibadah Haji). The manual module of accounting on hajj cost has not details regulated the management of the cost. It simply contains a simulation for a training in arranging general accounting report ranging from note taking and general financial report making. In this context, The Ministry of Religious Affair needs to coordinate with some related parties such as IAI, standing for Ikatan Ahli Akuntansi, Accounting Expert Association in formulating accounting standard of hajj cost and developing an accounting information application system so that the report of hajj cost management could be more comprehensively accountable.
\end{abstract}

Keywords: Accountancy, BPIH, Ministry of Religious Affair.

\begin{abstract}
ABSTRAK
Standar akuntansi merupakan konsep dasar yang sangat diperlukan dalam penyusunan dan pengembangan pedoman penyelenggaraan akuntansi atas suatu asset, utang maupun ekuitas dalam pengelolaan Biaya Penyelenggaraan Ibadah Haji (BPIH). Modul pedoman akuntansi Biaya Penyelenggaraan Ibadah Haji saat ini belum mengatur secara detail terkait dengan pengelolaan BPIH, yakni modul tersebut hanya sebagai bahan latihan untuk pelatihan pedoman akuntansi penyelenggaraan BPIH yang mengatur pencatatan dan pembuatan laporan keuangan secara umum. Kementerian Agama perlu melakukan koordinasi kepada pihak terkait seperti Ikatan Ahli Akuntansi (IAI) dalam merumuskan standar akuntasi (PSAK) BPIH dan mengembangkan sistem aplikasi informasi akuntansi agar pelaporan pengelolaan keuangan BPIH bisa lebih komprehensif dan lebih dapat dipertanggung jawabkan.
\end{abstract}

Kata kunci: Akuntansi, Biaya Penyelenggaran Ibadah Haji (BPIH), Kementerian Agama.

\section{Pendahuluan}

Haji merupakan salah satu rukun Islam kelima yang diwajibkan bagi setiap orang Islam yang mampu mengerjakannya. Penyelenggaran haji di Indonesia telah melewati durasi yang panjang yaitu dimulai sejak kerajaan Islam berdiri di nusantara. Sejak dahulu jumlah jemaah haji selalu bertambah setiap tahunnya padahal membutuhkan waktu berbulan-bulan untuk bisa sampai ke Mekkah di Arab Saudi karena saat itu belum terdapat pesawat terbang. Transportasi saat itu hanyalah menggunakan tranportasi darat dan kapal laut.
Seiring dengan semakin membaiknya tingkat kesejahteraan ekonomi masyarakat, animo masyarakat yang ingin berhaji terus meningkat, bahkan melebihi kuota yang ditetapkan. Pada tahun 2004 banyak masyarakat yang tidak dapat berangkat haji karena jumlah mereka sudah melebihi kuota. Akibatnya, terjadilah waiting list (daftar tunggu) jemaah haji sekitar 30.000 orang dan terus bertambah di setiap tahunnya. Pemerintah sebagai regulator sekaligus pengawas penyelenggaraan ibadah haji di Indonesia akhirnya melalui Kementrian Agama menyiapkan sistem tata kelola haji dengan penerapan Ongkos Naik Haji $(\mathrm{ONH})$, yaitu dengan sistem pembayaran lunas dan 
tabungan (cicilan) atau pilihan tahun keberangkatan. Untuk menunjang sistem tersebut lalu dikembangkan aplikasi sistem informasi dan komputerisasi haji terpadu (SISKOHAT).

Dalam mempermudahkan sistem pendaftaran dan mempersempit waiting list (daftar tunggu), sejak 1 Mei tahun 2010 pemerintah memberlakukan sistem pendaftaran sepanjang tahun dengan setoran awal Rp. 25.000.000,-("Peraturan Menteri Agama No. 6 Tahun 2010 tentang Prosedur dan Persyaratan Pendaftaran Jemaah Haji,” 2010)[3]. Prinsip pendaftaran didasarkan pada nomor urut pendaftaran/ nomor porsi, yang kemudian dikenal dengan istilah first come first served. Dengan demikian jemaah haji Akan memperoleh perlindungan dan kepastian untuk berangkat ke tanah suci.

Kementerian Agama selaku instansi pemerintah yang diamanahi tugas untuk mengelola dana haji, perlu memiliki sistem tata kelola akuntansi yang baik agar pelayanan jemaah haji berjalan secara maksimal. Menteri/pimpinan lembaga sebagai pengguna anggaran/pengguna barang mempunyai tugas untuk menyusun dan menyampaikan laporan keuangan kementerian Negara/lembaga yang dipimpinnya. Laporan kuangan adalah wujud konkret transparansi dan akuntabilitas pengelolaan keuangan negara yang setidak-tidaknya terdiri dari laporan realisasi anggaran, neraca, laporan arus kas dan catatan atas laporan keuangan ("UndangUndang Nomor 17 Tahun 2003 Tentang Keuangan Negara," 2003, p. Pasal 9 Ayat (g))[1].

Saat ini dana masyarakat yang berupa Biaya Penyelenggraan Ibadah Haji (BPIH) yang terakumulasi di rekening Kementerian Agama sudah mencapai triliunan rupiah dan tidak dimasukkan kedalam keuangan Negara. Oleh karena itu perlakuan pengelolaan dana BPIH harus mendapatkan perhatian khusus agar terhindar dari penyimpangan oknum yang tidak bertanggung jawab mengingat perlakuan akuntansi dana haji BPIH belum menggunakan pernyataan standar akuntansi (PSAK) seperti apa yang telah di sampaikan Bapak Anggito Abimanyu disela acara peresmian gedung Itjen Kementerian Agama di Jakarta.(Akuntanonline, 2014) [2]

Adapun standar akuntansi yang digunakan dalam pembuatan laporan biaya penyelenggaraan ibadah haji, Kementerian Agama menggunakan Modul Pedoman Akuntansi Biaya Penyelenggaraan Ibadah Haji yang diterbitkan oleh Tim Peningkatan Kualitas Laporan Keuangan Penyelenggaraan Ibadah Haji Kementerian Agama Republik Indonesia. Pada kesempatan ini peneliti bermaksud untuk menyampaikan analisis perlakuan akuntansi terhadap pengelolaan dana penyelenggaraan ibadah haji. Penelitian ini diharapkan dapat membuat pembaca lebih mengenal dan memahami perlakuan akuntasi pengelolaan BPIH di Indonesia yang pada tahap selanjutnya tikut berpartisipasi dalam memberikan kontribusi positif terhadap pengembangan sistem akuntansi Pengeloaan Dana Biaya Penyelenggaraan Ibadah Haji (BPIH) kedepannya.

\section{Macam - Macam Sumber Pendanaan Penyelenggaraan Ibadah Haji}

Menurut Direktorat Jenderal Pengelolaan Haji dan Umrah Kementerian (Direktorat Jenderal Pengelolaan Haji dan Umrah Kementerian Agama, 2012)[3], macam-macam sumber pendanaan penyelenggaraan ibadah haji, terdiri dari:

a. Anggaran APBN

Sebelum ditetapkannya Undang -Undang No. 17 Tahun 1999 Tentang Penyelenggaraan Ibadah Haji, seluruh komponen pembiayaan ibadah haji ditanggung sepenuhnya oleh jamaah. Pada tahun 2004, untuk pertama kalinya pemerintah mengalokasikan APBN untuk penyelenggaraan haji sebesar Rp. 46.000.000,-. Dana tersebut digunakan untuk pengadaan obat-obatan dan alat kesehatan sebagai konsekuensi pelaksanaan amanat undang-undang tersebut.

Pada priode selanjutnya, anggaran APBN untuk penyelenggaraan haji diperluas penggunaanya, tidak hanya untuk kesehatan akan tetapi juga untuk membiayai panitia penyelenggaraan ibadah haji (PPIH) pusat, embarkasi, bahkan pelatihan petugas kloter maupun non-kloter. Adapaun anggaran APBN untuk mendukung kelancaran penyelenggraan haji di kementerian agama pada tahun 2012 sekitar Rp252.167.873.000 dan kementerian kesehatan sejulah Rp400.000.000.000,-.

b. Biaya Penyelenggaraan Ibadah Haji

BPIH merupakan sejumlah Dana yang harus dibayar oleh masyarakat untuk dapat menunaikan ibadah suci. Sesuai dengan Undang-Undang No 13 Tahun 2008 Tentang Penyelenggaraan Ibadah Haji, BPIH disetorkan ke rekening menteri agama melalui bank syariah atau bank umum nasional yang ditunjuk oleh menteri agama dan dikelola oleh Kementerian Agama dengan mempertimbangkan nilai manfaat. Hasil manfaat tersebut digunakan langsung untuk pembiayaan operasional haji.

BPIH dapat terdiri dari setoran awal dan setoran lunas, meliputi dua komponen, yaitu direct cost dan indirect cost. Direct cost adalah biaya yang dibebankan secara langsung kepada jemaah haji yang digunakan untuk menyelenggarakan ibadah haji. Besaran komponen direct cost ditetapkan oleh presiden dalam bentuk Peraturan Presiden atas usul 
menteri agama setelah mendapatkan persetujuan DPR-RI. Adapun yang dimaksud dengan indirect cost adalah biaya yang dibebankan dari hasil optimalisasi Dana setoran awal BPIH yang digunakan untuk biaya operasional penyelenggaraan ibadah haji. Besaran komponen indirect cost BPIH diusulkan oleh menteri agama dan digunakan setelah mendapatkan persetujuan DPR-RI (Aidi Johansyah, 2014)[5].

Dalam pendayagunaannya, BPIH diggunakan untuk membiayai kegiatan penyelenggaran haji yang meliputi biaya penerbangan, operasional di tanah air, operasional di Arab Saudi dan living cost. Biaya penerbangan di tanah air meliputi pengadaan buku dan bimbingan manasik haji, akomodasi dan konsumsi jemaah di embarkasi, pembuatan paspor dan visa, pengadaan gelang jemaah, operasional siskohat, pelayanan pada kanwil dan kantor Kemenag kabupaten dan kota.

Biaya operasional di Arab Saudi meliputi pembiayaan untuk general service jemaah, pemondokan dan katering jemaah, tranportasi lokal jemaah, pelayanan arafah-mina, safari wukuf, badal haji, sewa gedung pelayanan, akomodasi dan katering petugas haji serta dukungan manajemen haji. Living cost merupakan salah satu komponen yang pada dasarnya merupakan titipan karena dikembalikan secara utuh kepada jemaah haji untuk bekal selama di Arab Saudi, khususnya untuk makan selama di makkah dan pembayaran dam. Living cost diberikan sebanyak SAR1.500 yang penyerahannya dilakukan di asrama haji saat pemberangkatan jemaah (Direktorat Jenderal Pengelolaan Haji Dan Umrah Kementerian Agama, 2012)[4].

Biaya penerbangan merupakan biaya terbesar setiap tahunnya yaitu sekitar $53-57 \%$ per tahnnya. Semula pemerintah menerapkan besaran BPIH yang Sama untuk setiap komponen tiket penerbangan untuk setiap embarkasi. Namun tahun 2006 pemerintah menggantinya dengan berdasarkan pada jarak tempuh setiap embarkasi ke Arab Saudi dan yang menentukan besaran biayanya adalah DPR-RI (Direktorat Jenderal Pengelolaan Haji Dan Umrah Kementerian Agama, 2012) [3]. Disamping mempertimbangkan harga tiket penerbangan, besarnya BPIH juga melihat fluktuasi nilai tukar valuta asing, kondisi perekonomian, tingkat inflasi, dan perolehan hasil optimalisasi setoran awal BPIH.

Dengan Adanya kebijakan sistem pendaftaran first come first served, serta mengindari permainan spekulan dan jual beli seat/ porsi, pemerintah menetapkan setoran awal BPIH sebesar Rp. 25.000.000,-. Sampai 31 maret 2012, sudah terkumpul sebanyak Rp. 41.208.292.792.677,-. Dan Akan semakin membesar sesuai perkembangan jumlah pendaftar haji. Setoran Dana BPIH ke rekening Kementerian Agama semakin bertambah disetiap tahunnya. Agar Dana yang terkumpul tidak hanya mengendap dan lebih bermanfaat, Dana tersebut dioptimalisasi oleh Kementerian Agama melalui pembelian Surat Berharga Syariah Negara (SBSN/sukuk) dan deposito syariah. Pembelian sukuk pertama kalinya dilakukan pada masa menteri agama Muhammad M. Basyuni dengan menandatangani nota kesepahaman (MOU) dengan menteri keuangan pada tanggal 21 April 2019. Dalam pembelian tersebut disepakati pembelian dilakukan secara bertahap dan tidak dapat diperdagangkan (non tradeable), serta imbalan di atas deposito. Sampai 31 Maret 2012, penempatan BPIH pada sukuk/SBSN sebesar Rp28.000.000.000.000.-. Sedangkan dalam bentuk giro sebesar Rp3.753.892.792.677.dan deposito sebesar Rp9. 454. 400.000.000.-.

\section{c. Dana Abadi Umat}

Dana abadi umat merupakan Dana yang diperoleh dari sisa operasional penyelenggraan ibadah haji melalui efisiensi dari BPIH dan sumber lainnya, baik komponen direct cost maupun indirect cost setelah kegiatan dilaksanakan sesuai dengan rencana. Pengelolaan DAU dilakukan oleh Badan Pengelola Dana Abadi Umat (BPDAU) yang diketuai oleh menteri agama dan dibantu oleh dewan pelaksana (Board of directors) dan dewan pengawas.

Dana abadi umat dapat digunakan untuk pelayanan ibadah haji, penidikan dan dakwah, kesehatan, socsial keagamaan, ekonomi serta pembangunan sarana dan prasarana ibadah.Pembiayaan yangdiperlukan bagi pengelolaan DAU diatur dalam pasal 19 Keppres N0.22/2001 yang rinciannya diatur oleh keputusan menteri agama. Pada tahun 2004, terdapat usulan untuk menyempurnakan/ merevsi Undang-Undang No 17 tahun 1999 sekaligus penyempurnaan tata kelola Dana DAU.

Dengan adanya ususlan revisi undang-undang tersebut, sejak 16 Mei tahun 2005 menteri agama Muhammad M. Baisyuni membekukan penggunaan DAU, lalu mengusulkan kepada Bapak Presiden untuk menyempurnakan keppres no.22/2001 tentang pengelolaan DAU. Pengawasan Dana DAU dilakukan oleh BPK yang hasilnya disampaikan kepada DPR. Di samping itu, untuk pengendalian internal, sewaktu-waktu Inspektorat Jenderal Kementerian Agama mengaudit DAU. Laporan keuangan DAU juga menjadi lampiran laporan keuangan kementerian agama kepada pemerintah yang disampaikan melalui menteri keuangan.

Pada waktu serah terima jabatan menteri agama RI pada 24 Oktober 2004, jumlah DAU sebesar 
Rp382.102.574.907 dan USD 77.120.643, 12. Saldo dana DAU per 31 Januari 2009 sebesar Rp701.728.340.367,48 dan USD 79.731.033,59 (Ditjen Penyeleggaraan Haji dan Umrah Kementerian Agama RI, 2010)[6]. Posisi DAU pada saat serah terima dari menteri agama Muhammad M. BAisyuni kepada menteri agama Suryadharma Ali tanggal 22 Oktober 2010 sebesar Rp779.374.605.344,14 dan USD 80.645.054,36. Posisi DAU s.d 31 Maret 2012 sebesar Rp382.001.560.064,66 dan USD 100.029.890,49. Selain itu dalam bentuk kepemilikan saham pada Bank Muamalat Indonesia (BMI) yaitu sebesar RP19.990.000.000,-. Disamping itu, memperoleh bonus saham sebesar Rp556.383.000, - sehingga total saham menjadi Rp20.556.383.000,-. Sebagian dana juga termasuk SBSN/sukuk yaitu sebesar Rp783.000.000.000,- (Direktorat Jenderal Pengelolaan Haji dan Umrah Kementerian Agama, 2012)[4].

\section{Perbandingan Pengelolaan Dana Haji di Malaysia dan Indonesia}

Pengelolaan dan penyelenggaraan haji di Malaysia dilakukan oleh lembaga pemerintah yang bernama Lembaga Tabung Haji. Tabung haji Malaysia memiliki keleluasaan dalam melakukan berbagai investasi dalam bisnis sejak 30 September 1963. Saat ini Lembaga Tabung Haji Malaysia sudah menjadi lembaga keuangan. Investasinya antara lain dalam bentuk kereta API cepat yang menghubungkan pusat Kota dengan bandara internasional kuala lumpur. Adapun bentuk investasi lainnya berupa perkebunan kelapa sawit di Riau, Indonesia, yang mampu memberikan keuntungan paling besar. Pada tahun 2003, dana yang dikelola Tabung Haji Malaysia mencapai Rm 10,23 milyar dalam bentuk investasi dan portofolio oleh para ahli keuangan tabungan haji (Direktorat Jenderal Pengelolaan Haji dan Umrah Kementerian Agama, 2012)[4]. Keuntungan tabungan haji Malaysia tidak hanya dari pengelolaan setoran awal, namun juga diperoleh dari pengelolaan tabungan, investasi dan bisnis. Dari usaha Tabung Haji ini diperoleh keuntungan untuk memberikan subsidi pembayaran biaya haji bagi jemaah haji Malaysia.

Adapun di Indonesia, sebelum dibentuknya Badan Pengelola Keuangan Haji (BPKH), pengelolaan dana haji di Indonesia dliakukan oleh lembaga pemerintah yang bernama Direktorat Penyelenggaraan Haji dan Umrah. Dana haji di Indonesia terdiri dari setoran awal BPIH, setoran lunas BPIH, dan Dana Abadi Umat. Kementerian Agama mengelola Dana tersebut berdasarkan peraturan peundang-undangan agar Dana yang mengendap dapat lebih bisa dioptimalkan dan memperoleh nilai manfaat. Tidak adanya kejelasan hukum mengenai kewenangan Kementerian Agama dalam memanfaatkan Dana haji diluar perbankan dan Surat berharga menyebabkan pendayagunaan Dana haji hanya sebatas investasi di bidang SBSN/Sukum, deposito syariah dan rekening giro sehingga belum dapat memberdayakan ekonomi riil masyarakat.

Melihat pengelolaan Dana haji Indonesia yang kurang maksimal dalam pemanfaatannya, maka perlu dirumuskan suatu regulasi yang dapat memberikan landasan hukum tentang kedudukan keuangan haji, kewenangan pengembangan Dana haji dan badan pengembangan keuangan haji. Pemerintah menyatakan akan segera membentuk badan hukum publik yang bertugas untuk melakukan penerimaan, pengembangan, pengeluaran dan pertanggung jawaban keuangan haji yang bernama Badan Pengelolaan keuangan Haji (BPKH) ("Undang-Undang Republik Indonesia Nomor 34 Tahun 2014 Tentang Pengelolaan Tabungan Haji," 2014, p. Bab 3 Pasal 1)[7].

Kehadiran lembaga independen Badan Pengelolaan Keuangan Haji (BPKH) kedepannya diharapkan dapat memaksimalkan pengelolaan dan pengembangan dana haji dengan lebih transparan dengan mengacu pada standar akuntasi yang berlaku, sehingga masyarakat dapat turut serta dalam mengevaluasi dan memberikan masukan dalam tata kelola pengelolaan dana BPIH. Selain itu, Badan Pengelolaan Keuangan Haji (BPKH) diharapkan dapat memaksimalkan pengelolaan dana haji secara professional sehingga dapat memberikan subsidi bagi calon jamaah haji serta mampu memberdayakan ekonomi masyarakat secara umum.

\section{Tata Kelola Laporan Keungan Haji dalam Perspektif Akuntansi}

Pengelolaan Dana haji selalu mendapatkan sorotan dari masyarakat mengingat jumlah Dana yang terkumpul sangat besar. Pengelolaan Dana haji sering kali menjadi polemik, disatu sisi ada anggapan bahwa Kementerian Agama belum bisa memanfaatkan Dana haji yang besar untuk kemaslahatan umat dan bangsa, namun disisi lain, belum adanya kejelasan hukum bagi Kementerian Agama untuk memanfaatkan Dana haji di luar perbankan dan Surat berharga sehingga kurang mendorong perekonomian masyarakat di sector riil. Menteri Agama sebagai penanggung jawab penyelenggaraan ibadah haji berkewajiban menyelenggarakan akuntansi dan mempertanggungjawabkannya dalam bentuk laporan penyelenggaraan ibadah haji sebagaimana diatur dalam Pasal 25 Undang -Undang Nomor 13 Tahun 2008 Tentang Penyelenggaraan Ibadah Haji. 
Laporan keuangan penyelenggaraan ibadah haji terdiri dari laporan posisi keuangan, laporan aktivitas keuangan, laporan arus kas dan catatan atas laporan keuangan (CaLK) (Tim Peningkatan Kualitas Laporan Keuangan Penyelenggaraan Ibadah Haji Kementerian Agama, 2012)[8].

Berdasarkan hasil wawancara dengan Aidi Johansyah selaku Kasi Pengelolaan Keuangan Haji Kemenag Kanwil DI Yogyakarta pada hari Rabu 31 Desember 2014, beliau menyatakan bahwa BPIH bukanlah keuangan Negara dan saat ini memang belum ada aturan yang mengatur secara teknis cara penyusunan laporan pengelolaannya akan tetapi kedepannya akan ada peroses pembuatan laporan keuangannya berdasarkan prinsip pernyataan standar akuntansi (PSAK) Indonesia. Adapun penyusunan laporan keuangan BPIH saat ini menggunakan Modul Pedoman Akuntansi Biaya Penyelenggaraan Haji dari Tim Peningkatan Kualitas Laporan Keuangan Haji Kementerian Agama Republik Indonesia. Meskipun belum menggunakan standar PSAK, pedoman akuntansi BPIH sudah mencerminkan nilai-nilai yang terkandung dalam standar akuntansi PSAK. Kerangka dasar penyajian laporan keuangan BPIH yang terdapat dalam Modul Pedoman Akuntansi Biaya Penyelenggaraan Haji, Kementerian Agama sudah mengadopsi kerangka dasar PSAK diantaranya dengan menjelaskan ruang lingkup kerangka konseptual, tujuan pelaporan keuangan, asumsi dasar, karakteristik akuntansi yang digunakan, prinsip akuntansi yang digunakan,dan lainnya. Adapun jenis laporan keuangn BPIH terdiri atas laporan neraca, laporan operasional, laporan arus kas dan catatan atas laporan keuangan (CaLK).

Penyajian laporan keuangan yang wajar mensyaratkan penyajian secara jujur bahwa dampak dari transaksi, pristiwa, dan kondisi lain sesuai dengan definisi dan kriteria pengakuan aset, liabilitas, pendapatan dan beban yang diatur dalam Kerangka Dasar Penyajian Laporan Keuanngan (ED PSAK No.1 paragraf 13 Revisi 2009). Selain itu Penyajian secara wajar juga mensyaratkan bahwa suatu entitas untuk (a) memilih dan menerapkan kebijakan akuntansi berdasarkan PSAK 25. PSAK 25 mengatur hirarki pedoman otoritatif yang dipertimbangkan manajemen dalam hal tidak terdapat PSAK yang secara khusus mengatur suatu pos tertentu. (b) menyajikan informasi termasuk kebijakan akuntansi, sedemikian rupa sehingga dapat memberikan informasi yang relevan, andal, dapat diperbandingkan dan dapat dipahami, dan (c) memberikan pengungkapan tambahan jika kesesuaian dengan persyaratan khusus dalam SAK tidak cukup bagi pengguna laporan untuk memahami pengaruh dari transksi tertentu, pristiwa dan kondisi lain terhadap posisi keuangan dan kinerja keuangan entitas (Ikatan Akuntan Indonesia, 2009)[9].

Dalam aspek penyajian laporan keuangan secara wajar, modul 1 pedoman akuntansi BPIH menekankan penyajian laporan keuangan secara wajar baik dalam neraca, laporan aktivitas keuangan, laporan arus kas, laporan perubahan ekuitas dan catatan atas laporan keuangannya dengan memasukkan faktor pertimbangan sehat dan kehati-hatian (prudent) pada saat melakukan prakiraan akuntansinya, sehingga asset atau pendapatan tidak dinyatakan terlalu tinggi dan kewajiban tidak dinyatakan terlalu rendah. Adapun dalam hal pengungkapan lengkap (full disclosure), pedoman tersebut secara umum mengarahkan untuk menyajikan informasi secara lengkap atas informasi yang dibutuhkan oleh penggunanya yaitu dengan menempatkan informasi pengungkapan tersebut pada lembar muka (on the face) laporan keuangan atau pada catatan atas laporan keuangan tersebut.

\begin{tabular}{|c|c|c|c|}
\hline $\begin{array}{l}\text { Tahun } \\
2010\end{array}$ & $\begin{array}{l}\text { Tahun } \\
2011\end{array}$ & $\begin{array}{l}\text { Tahun } \\
2012\end{array}$ & $\begin{array}{l}\text { Tahun } \\
2013\end{array}$ \\
\hline $\begin{array}{ll}\text { Masalah: } \\
\text { a. } & \text { Kas dan } \\
\text { setoran } \\
\text { awal } \\
\text { b. Hasil } \\
\text { optimali } \\
\text { sasi } \\
\text { c. Asset } \\
\text { tetap } \\
\text { d. Pengelol } \\
\text { aan } \\
\text { DAU }\end{array}$ & $\begin{array}{l}\text { Masalah: } \\
\text { a. Setoran } \\
\text { awal } \\
\text { b. System } \\
\text { pendafta } \\
\text { ran } \\
\text { c. Pengelol } \\
\text { aan } \\
\text { DAU } \\
\text { d. Asset } \\
\text { tetap }\end{array}$ & $\begin{array}{l}\text { Masalah: } \\
\text { a. Integrasi } \\
\text { system } \\
\text { b. Setoran } \\
\text { DAU } \\
\text { c. Asset tetap }\end{array}$ & $\begin{array}{c}\text { Masalah: } \\
\text { Asset } \\
\text { tetap }\end{array}$ \\
\hline $\begin{array}{l}\text { Hasil audit: } \\
\text { Disclaimer }\end{array}$ & $\begin{array}{l}\text { Hasil } \\
\text { audit: } \\
\text { Wajar } \\
\text { dengan } \\
\text { pengecuali } \\
\text { an }\end{array}$ & $\begin{array}{l}\text { Hasil audit: } \\
\text { Wajar } \\
\text { dengan } \\
\text { pengecualian }\end{array}$ & $\begin{array}{l}\text { Hasil audit: } \\
\text { Wajar } \\
\text { tanpa } \\
\text { pengecuali } \\
\text { an dengan } \\
\text { paragraph } \\
\text { aset tetap }\end{array}$ \\
\hline
\end{tabular}

Secara time series, Kementerian Agama dapat dikatakan mulai berbenah dalam memperbaiki tata kelola pencatatan akuntansinya sehingga laporan tahunan pada tahun 2013 mendapatkan nilai wajar tanpa pengecualian dari Badan Pengawas Keuangan (BPK-RI) meskipun dalam catatannya harus ada pembenahan pembukuan dalam aset tetap. Adapun opini disclaimer BPK RI terhadap laporan keuangan penyelenggaraan haji dan umrah pada tahun 2010 disebabkan antara lain berkaitan dengan pemindahbukuan setoran awal haji yang dilakukan melalui SISKOHAT (sistem komputerisasi haji terpadu) yaitu adanya pembenahan dalam pemindahan bukuan setoran 
awal rekening nasabah kepada Rekening menteri Agama (Ditjen Penyeleggaraan Haji dan Umrah Kementerian Agama RI, 2010)[6].

Terkait dengan pernyataan bahwa Kementerian Agama belum terbuka dalam pengelolaan dana haji BPIH, Aidi Johansyah selaku Kasi Pengelolaan Keuangan Haji Kemenag Kanwil D.I. Yogyakarta dalam sesi wawamcara pada hari Rabu 31 Desember 2014 membantah hal tersebut. Aidi Johansyah menyatakan bahwa masyarakat belum memahami pengelolaannya, padahal laporan keuangannya sudah dipublikasikan di media. Selain itu, Aidi Johansyah menambahkan bahwa permasalahan dalam tata kelola laporan haji saat ini adalah permasalahan aset tetap, karena adanya pencampuran dana kekayaan yang bersumber dari APBN dan dari dana BPIH, misalnya dalam hal pembangunan gedung untuk pemondokan didanai melalui APBN sedangkan untuk meja dan kursinya misalkan dari dana BPIH.

Menurut analisis peneliti, dalam menilai suatu aset, akan lebih efektif lagi apabila sejak awal Kementerian Agama selalu melakukan pencatatan dalam pembelian aset tersebut kemudian memisahkannya dari kekayaan keuangan Negara. Sistem akuntansi yang lemah dalam pencataan dan pengendalian aktiva akan menyebabkan kerentanan dalam penyalah gunaan aktiva, hal ini disebabkan oleh beberapa faktor sebagai berikut (Boynton et al., 2002)[10]:

a. Tidak mencukupinya pencatatan berkenaan dengan aktiva akan menyebabkan kerentanan untuk disalahgunakan.

b. Kurangnya sistem yang sesuai atau otorisasi dan persetujuan transaksi (sebagai contoh, dalam pembelian).

c. Penjagaan fisik yang buruk terhadap kas, investasi, persediaan atau aktiva tetap.

d. Kurangnya dokumentasi transaksi yang tepat waktu dan sesuai (seperti dalam pembelian asset baik tunai maupun kredit).

Selain itu, berdasarkan hasil pengamatan peneliti Modul 1 pedoman akuntansi BPIH juga menyebutkan tentang tata cara pencatatan akuntansi aset dalam neraca keuangan, akan tetapi kurang menjelaskan secara teknis tata cara perlakuan akuntansinya secara detail sehingga berpotensi menimbulkan kekurangan dalam tata cara pemostingan dan penjurnalan akuntansinya.

Dalam menghitung penyusutan aktiva tetap, Modul 1 pedoman akuntansi BPIH menggunakan metode garis lurus, metode saldo menurun, dan metode unit produksi. Adapun kekurangan dari modul ini adalah belum menjelaskan metode penyusutan mana yang boleh dipilih untuk perhitungan penyusutan aktiva BPIH sehingga Akan menyebabkan perbedaan metode penyusutan antar
Kantor wilayah Kemenag. Oleh karena itu, modul ini kemudian menambahkan adanya penilaian kembali (revaluation) di akhir priode akuntansi atas asset BPIH (Tim Peningkatan Kualitas Laporan Keuangan Penyelenggaraan Ibadah Haji Kementerian Agama, 2012)[8]. Adapun dampak dari bervariasinya metode penyusutan aktiva yang digunakan Akan menyebabkan kurang efektif dan efisiennya pembuatan laporan keuangan konsolidasian antar Kantor Wilayah Kementerian Agama.

Yusuf Johan menyatakan, setidaknya ada tiga hal yang harus kita lihat untuk menilai apakah pengelolaan dana haji itu akuntabel (dapat dipertanggung jawabkan) atau tidak, yaitu faktor entitas, struktur biaya dan waktu penyelenggaraan ibadah haji . Dari segi entitas, badan yang mengelola dana untuk ibadah haji dari APBN dan dana haji cari calon jemaah haji harus jelas dan sebisa mungkin dari BPIH harus ada pemisahan dana secara akuntansi. Penggunaan dana haji yang dibiayai APBN harus dimasukkan kedalam laporan keuangan pemerintah sedangkan dana haji yang ditanggung melalui biaya penyelenggaraan ibadah haji (BPIH) yang berasal dari jemaah harus dilaporkan dalam laporan keuangan tersendiri seperti laporan keuangan penyelenggaraan haji. Dalam struktur biaya, pemerintah harus memaparkan struktur biaya yang jelas atas pelaksanaan suatu ibadah haji sebelum menentukan biaya penyelenggaraan ibadah haji kepada masyarakat, sehingga masyarakat mengetahui rincian biaya yang harus mereka bayar dan mengawasi peroses penggelolaan BPIH tersebut. Selanjutnya, Yusuf Johan menyatakan bahwa waktu penyelenggaraan ibadah haji haruslah jelas, guna mengetahui besaran margin/bunga dari setoran awal jemaah haji (dana optimalisasi) yang dihasilkan selama peroses menunggu pelaksanaan ibadah haji. Maka dari sisi pembukuan, harus jelas si A setor berapa dan dapat bunga berapa (Wartaekonomi, 2014)[11].

Aidi Johansyah dalam sesi wawancara pada rabu 31 Desember 2014 mengakui kekurangan dalam pengelolaan sistem akuntasi dana haji. Beliau menyatakan bahwa, dana optimalisasi yang diperoleh dari pengelolaan BPIH memang belum menerapkan sistem pembukuan terperinci mengingat dana optimalisasi (baik dalam bentuk sukuk maupun deposito syariah) yang berasal dari BPIH sebesar Rp25.000.000 yang disetorkan ke rekening Kementerian Agama akan menjadi keuntungan yang mengendap langsung di rekening tersebut karena menggunakan system one account yaitu atas nama rekening Kementerian Agama. Namun kedepannya, Kementerian Agama akan membenahi sistem pembukuan akuntansi BPIH kedalam nama rekening pribadi setiap calon 
nasabah. Aidi Johansyah juga menambahkan bahwa dana optimalisasi yang bersumber dari BPIH sebenarnya akan kembali kepada nasabah dalam bentuk pelayanan, seperti dalam kegiatan manasik haji dan biaya kegiatan penyelenggaraan haji lainnya.

Kementerian Agama dalam menginvestasikan dana BPIH baik dalam bentuk deposito syariah maupun instrumen lainnya dapat mengikuti standar akuntansi yang sudah berlaku di Indonesia. Salah satunya seperti PSAK 105 tentang akuntansi mudharabah yang dapat dijadikan suatu dasar acuan dalam menginvestasikan dana BPIH dengan mendasarkan pada fatwa Dewan Syariah Nasional Nomor 7 Tahun 2000 tentang Investasi Mudharabah. Standar akuntansi sangat diperlukan bagi Kementerian Agama dalam mempermudah pencatatan akuntansi dan menganalisis keuntungan investasi dari penyaluran dana BPIH tersebut.

Selain itu, pelaporan pengelolaan keuangan haji (BPIH) yang sudah dipublikasikan oleh Kementerian Agama melalui website Kementerian Agama menurut analisis peneliti merupakan salah satu langkah untuk mendapatkan kepercayaan masyarakat terutama dalam mewujudkan akuntabilitas dan transparansi akuntansi keuangan BPIH sehingga dalam hal ini masyarakat diberikan ruang untuk turut serta menganalisis siklus akuntansi penggunaan dana BPIH di lingkungan Kementerian Agama. Transparansi merupakan aspek penting yang sangat dibutuhkan dalam penyajian laporan keuangan BPIH agar penyalahgunaan dana BPIH dapat diminimalisir sedini mungkin mengingat penyelenggaraan haji kerap kali membawa masalah tertentu dalam tiap tahunnya seperti kualitas katering yang menurun, masalah pemondokan, hingga pengadaan sarana dan prasarana ibadah haji yang dirasa kurang maksimal.

Selain itu, Kementerian Agama perlu membenahi sistem pemcatatan laporan keuangannya dengan menerapkan sistem sentralisasi informasi akuntansi yang berbasisi IT karena saat ini pembuatan laporan keuangan haji di Kementerian Agama masih menggunakan input manual. Titik Nur Farihah selaku Staf Pembinaan Haji dan Umrah Kementerian Agama Kanwil D.I Yogyakarta pada sesi wawancara pada Selasa 06 Januari 2015 menyatakan bahwa pengelolaan sistem pembuatan laporan keuangan BPIH di Kementerian Agama masih menggunakan input manual, yaitu belum ada sistem aplikasi khusus untuk menginput biaya penyelenggaraan haji BPIH. Titik Nur Farihah juga menambahkan bahwa kekurangan sistem akuntansi yang berbasis manual ini dapat menyebabkan perbedaan pencatatan akuntansi antar provinsi terutama dalam memasukkan pos biaya-biayanya.
Kementerian Agama mungkin bisa mengembangkan sistem aplikasi sentralisasi akuntansi. Sistem sentralisasi dilaksanakan dengan menggunakan suatu sisitem aplikasi akuntansi yang terintegrasi ke setiap Kantor Wilayah Kementerian Agama, sehingga pembukuan terhadap transakasitransaksi yang terjadi di setiap Kantor Wilayah Kementerian Agama diselenggarakan sepenuhnya oleh pusat. Pada mekanisme sentralisasi tersebut, Kantor Wilayah Kementerian Agama cukup mengumpulkan dokumen-dokumen biaya BPIH dan bukti-bukti lain yang mendukung terhadap pengeluaran kas dan peneriman kas BPIH sehingga rekening-rekening pembukuan di Kantor Wilayah Kementerian Agama di setiap daerah langsung terintegrasi dengan rekening-rekening pembukuan di Kantor Kementerian Agama pusat. Sistem pencatatan akuntansi yang sudah terintegrasi tersebut diharapkan dapat menghemat biaya administrasi dan lebih menjamin adanya keseragaman prosedur serta metode-metode pembukuan yang diterapkan baik untuk aktivitas Kantor pusat Kementerian Agama di pusat maupun aktivitas Kantor Kementerian Agama di daerah.

Sebastian botzem menyatakan bahwa “organization's main sources of effectiveness and power is its ability to define the relevant body of knowledge and to translate it into normative prescriptions thatguide both the financial reporting of corporations and the development of accounting standards at the national level. It does so by drawing on notions of professionalism, which constitute the claim for a singular position in transnational accounting standardization. With regard to the organizational set-up, consultation procedures are particularly relevant as modes of legitimation. At the same time, consultation remains a powerful tool for exerting control over the definition of standards" (Sebastian Botzem, 2014)[12]. Oleh karena itu, kementerian agama kedepannya dapat berkoordinasi dengan Ikatan Akuntansi Indonesia (IAI) dalam menyusun dan mengembangkan pedoman akuntansi PSAK tentang Biaya Penyelenggaraan Ibadah Haji (BPIH). Adanya sinergitas antara Kementerian Agama dengan IAI beserta isntansi terkait lainnya diharapkan dapat menghadirkan laporan keuangan BPIH yang lebih efektif dan akuntabel (dapat dipertanggung jawabkan) karena IAI akan selalu turut serta dalam mengembangkan dan mengevaluasi kekuranga-kekurangan dalam penyusunan sistem akuntansi laporan keungan BPIH..

\section{Kesimpulan}

Pengelolalan Dana haji di Indonesia belum memiliki standar acuan akuntansi yang mengatur secara detail terkait dengan teknis pembuatan 
laporan keuangan BPIH sehingga memungkinkan adanya penyalahgunaan praktik pembukuannya. Dengan dirumuskannya Badan Penyelenggara Keuangan Haji (BPKH), pemerintah dan DPR RI harus membuat aturan yang jelas dan terperinci baik dalam hal penerimaan, pengembangan, pengeluaran dan pertanggung jawaban keuangan haji. Oleh karena itu, penyusunan sistem standarisasi akuntansi perlu diperhatikan agar pengelolaan biaya Dana haji tersebut lebih efektif dan lebih transparan kedepannya sehingga masyarakat dapat turut serta dalam mengevaluasi pelaksanaannya.

Selain itu, Kementerian Agama harus segera membangun sistem aplikasi akuntansi berbasis IT yang terhubung dari Kantor Kementerian Agama yang berada di pusat (Jakarta) hingga ke daerah sehingga agar pembukuan dan pelapaoran akuntansi haji lebih efektif dan efisien. Sistem akuntansi yang tersentralisasi tersebut selain meringankan biaya adminstrasi juga dapat menghasilkan laporan keuangan yang lebih akuntabel dan real time, sehingga terhindar dari kesalahan dalam pencatatan dan penyusunan laporan keuangan antar wilayah kantor kementerian agama.

Evaluasi dan koordinasi dengan pihak terkait harus selalu mendapatkan perhatian dari Kementerian Agama, mengingat penyelenggaraan ibadah haji melibatkan banyak kementerian dan instansi, seperti kemeterian keuangan, tranportasi, kesehatan, sarana-prasarana, keamanan dan akomodasi lainnya. Apabila evaluasi dan koordinasi antar pemangku kepentingan tersebut dijalankan, niscaya kelemahan dan kekurangan dalam penyelenggaraan dan pelaporan keuangan dana haji dapat ditekan seminimal mungkin, sehingga dari tahun ke tahun jemaah haji akan berdampak pada kualitas pelayanan haji yang semakin baik.
[5] Aidi Johansyah, 2014. Pola Pengelolaan Keuangan Haji.

[6] Ditjen Penyeleggaraan Haji dan Umrah Kementerian Agama RI, 2010. Intisari Langkah-Langkah Pembenahan Haji. Ditjen Penyeleggaraan Haji dan Umrah Kementerian Agama RI, Jakarta.

[7] Undang-Undang Republik Indonesia Nomor 34 Tahun 2014 Tentang Pengelolaan Tabungan Haji, 2014.

[8] Tim Peningkatan Kualitas Laporan Keuangan Penyelenggaraan Ibadah Haji Kementerian Agama, 2012. Modul 1 Pedoman Akuntansi Biaya Penyelenggaraan Ibadah Haji. Dirjen Penyelenggraan Haji dan Umrah, Jakarta.

[9] Ikatan Akuntan Indonesia, 2009. ED PSAK No.1 paragraf 15 revisi 2009 tentang Penyajian Laporan Keuangan.

[10] Boynton, Johnson Kell, Kell, 2002. Modern Auditing. Erlangga, Jakarta.

[11] Wartaekonomi, 2014. IAI: Tiga Penilaian Akuntabilitas Pengelolaan Dana Haji.

[12] Sebastian Botzem, 2014. Transnational Standard Settingin Accounting: Organizing Expertise-Based Self-Regulation Intimes Of Crises. Emerald Insight, Accounting, Auditing \&Accountability Journal Vol. 27 No. 6.

\section{DAFTAR PUSTAKA}

[1] Undang-Undang Nomor 17 Tahun 2003 Tentang Keuangan Negara, 2003.

[2] Akuntanonline, 2014. Dana Pengelolaan Haji Akan Gunakan PSAK.

[3] Peraturan Menteri Agama No. 6 Tahun 2010 tentang Prosedur dan Persyaratan Pendaftaran Jemaah Haji, 2010.

[4] Direktorat Jenderal Pengelolaan Haji dan Umrah Kementerian Agama, 2012. Haji dari Masa Kemasa. Direktorat Jenderal Pengelolaan Haji dan Umrah Kementerian Agama, Jakarta. 